\title{
The influence of ozone concentration on the lower ionosphere - modelling and measurements during the 29-30 October 2003 solar proton event
}

\author{
A. Osepian ${ }^{1}$, S. Kirkwood ${ }^{2}$, and P. Dalin ${ }^{2}$ \\ ${ }^{1}$ Polar Geophysical Institute, Chalturuna 15, 183010 Murmansk, Russia \\ ${ }^{2}$ Swedish Institute of Space Physics, P.O. Box 812, 98128 Kiruna, Sweden
}

Received: 8 September 2008 - Revised: 18 December 2008 - Accepted: 13 January 2009 - Published: 5 February 2009

\begin{abstract}
A numerical model of D-region ion chemistry is used to study the influence of the ozone concentration in the mesosphere on ion-composition and electron density during solar proton events (SPE). We find a strong sensitivity in the lower part of the D-region, where negative ions play a major role in the ionization balance. We have chosen the strong SPE on 29-30 October 2003 when very intense proton fluxes with a hard energetic spectrum were observed. Deep penetration into the atmosphere by the proton fluxes and strong ionisation allows us to use measurements of electron density, made by the EISCAT $224 \mathrm{MHz}$ radar, starting from as low as $55 \mathrm{~km}$. We compare the electron density profiles with model results to determine which ozone concentration profiles are the most appropriate for mesospheric altitudes under SPE conditions. We show that, during daytime, an ozone profile corresponding to depletion by a factor of 2 compared to minimum model concentrations for quiet conditions (Rodrigo et al., 1986), is needed to give model electron density profiles consistent with observations. Simple incorporation of minor neutral constituent profiles ( $\mathrm{NO}, \mathrm{O}$ and $\mathrm{O}_{3}$ ) appropriate for SPE conditions into ion-chemistry models will allow more accurate modeling of electron and ion densities during such events, without the need to apply a complete chemical model calculating all neutral species.
\end{abstract}

Keywords. Atmospheric composition and structure (Middle atmosphere - composition and chemistry) - Ionosphere (Ion chemistry and composition; Polar ionosphere)

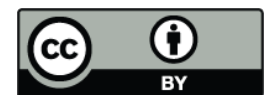

Correspondence to: S. Kirkwood (sheila.kirkwood@irf.se)

\section{Introduction}

Minor neutral constituents play a significant role in the processes controlling the ionization balance in the lower ionosphere. They are, as a rule, input parameters into theoretical models which compute ion composition, electron density $\left(N_{e}\right)$, and other ionosphere characteristics. Both experimental data and the results of theoretical investigations demonstrate a large variability in minor constituents, in particular, in the ozone concentration $\left[\mathrm{O}_{3}\right]$ at the altitude of the mesosphere. Theoretical investigations allow us to understand the nature of and reasons for such variability. Models of the minor constituents in the mesosphere have revealed the processes controlling photochemical and dynamical sources and sinks of each component. They have shown that the number density of the minor neutral constituents depends on solar illumination, geomagnetic activity, ionization sources, season, downward transport, turbulence, molecular and eddy diffusions and other factors. To obtain accurate numerical estimations of parameters describing the structure of the ionosphere during any specified geophysical situation, it is very important to incorporate, into the model, reasonable height profiles of the minor neutral components that are appropriate to the given geophysical conditions. The influence of the concentration of nitric oxide on the $N_{e}$ height-profile has been considered by Verronen et al. (2002). The role of the atomic oxygen concentration in forming the electron density profile during a solar proton event (SPE) has been investigated, in particular, by Osepian et al. (2008). Ondraskova et al. (2008) have considered the influence of solar illumination on the ion-chemistry and $N_{e}$ profile, comparing modelled responses between polar night and polar day. Although they briefly mention the role of ozone they do not make any

Published by Copernicus Publications on behalf of the European Geosciences Union. 

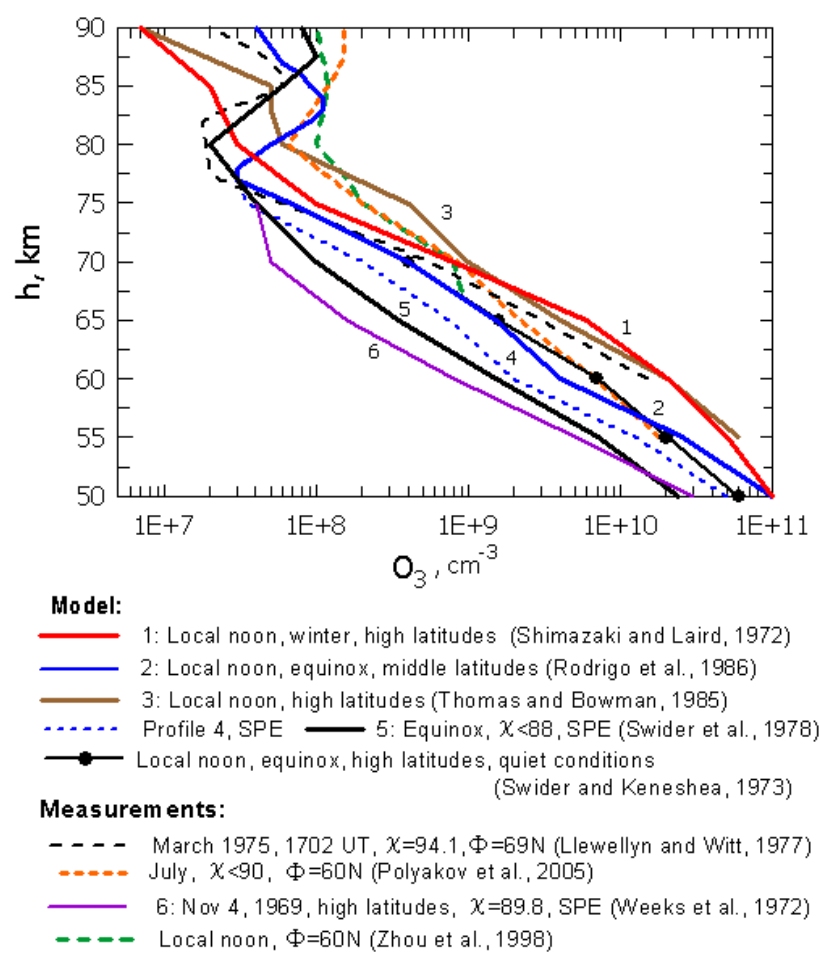

Fig. 1. Examples of the height distribution of the ozone concentration in the D-region obtained from measurements and from theoretical studies.

quantitative study of the sensitivity of the $N_{e}$ profile to the ozone profile.

In this study, we use numerical modelling to investigate the role of ozone in the ionization balance at different mesospheric altitudes and the influence of the ozone concentration, $\left[\mathrm{O}_{3}\right]$, as it changes due to the effects of solar proton precipitation, on the height distribution of the ion and electron densities during the SPE on 29-30 October 2003, also known as one of the "Halloween Storms". We use a theoretical model of the D-region and available height profiles of ozone in the mesosphere, measured or deduced with different diffusive-photochemical models. For calculation of the ionization rates we use code developed by Kirkwood and Osepian (1995) with input data on the differential solar proton fluxes in the energy range $2.4-300 \mathrm{MeV}$ measured by the satellites GOES-10 and GOES-11 (http://spidr.ngdc. noaa.gov/spidr/index.jsp). Then we combine the results of the modelling with measurements of electron density in the lower ionosphere made by the EISCAT $224 \mathrm{MHz}$ radar (geographic coordinates $69.6^{\circ} \mathrm{N}, 19.3^{\circ} \mathrm{E}$ ) to determine which ozone concentration profiles are most appropriate for mesospheric altitudes in conditions of solar proton precipitation. We use the theoretical model of the ionisation-recombination cycle of the D-region which was developed by Smirnova et al. (1988), Kirkwood and Osepian (1995), Osepian and Smirnova (1997). Tests of the model have shown that it reproduces both $N_{e}$ absolute values and the shape of $N_{e^{-}}$ profiles measured by the EISCAT radar during auroral activity, for altitudes above 70-75 km (Osepian et al., 1996; Kirkwood et al., 2001) and during SPE at altitudes above 65-70 km (Osepian et al., 2008).

In Sect. 2 we present a brief review of modern knowledge concerning the height distribution of ozone concentration in the mesosphere for different geophysical conditions. In Sect. 3 we examine the influence of the ozone concentration on the ion composition and electron density in the mesosphere. We estimate the efficiency of the reactions in the processes of transformation of primary negative $\mathrm{O}_{2}^{-}$and $\mathrm{O}^{-}$ions into intermediate complex ions $\mathrm{O}_{3}^{-}, \mathrm{O}_{4}^{-}, \mathrm{NO}_{4}^{-}, \mathrm{NO}_{3}^{-}$ and $\mathrm{NO}_{3}^{-}$to understand the role of reactions with ozone in the ionisation balance at each altitude during SPE. Comparison of theoretical and experimental $N_{e}$-profiles then allows us to estimate ozone concentrations which correspond to SPE.

\section{Height profiles of ozone in the mesosphere}

Ozone is continually formed and destroyed in the mesosphere. Figure 1 presents examples of the height distribution of the $\mathrm{O}_{3}$ concentration in the mesosphere during daytime, obtained from measurements and as a result of theoretical studies. Measurements show substantial diurnal variations at mesospheric altitudes with maximum concentrations at nighttime and a secondary peak above $80 \mathrm{~km}$ (Llewellyn and Witt, 1977; Weeks et al., 1972, 1978; Wilson and Schwartz, 1981; Ulwick et al., 1987; Zommerfields et al., 1989; Zhou et al., 1998; Sandor et al., 1997; Gumbel et al., 1998; Fussen et al., 2000; Kaufmann et al., 2003; Polyakov et al., 2005; Kyrölä et al., 2006).

The height distribution of the $\mathrm{O}_{3}$-density in the mesosphere, its seasonal and diurnal variations and the secondary peak have been explained by theoretical investigations and by modelling (Shimazaki and Laird, 1970, 1972; Ogawa and Shimazaki, 1975; Swider et al., 1978; Keneshea et al., 1979; Thomas and Bowman, 1985; Rodrigo et al., 1986; Sandor et al., 1997; Marsh et al., 2003; Jackman et al., 1995, 2005). The primary chemical production mechanism for odd oxygen in the thermosphere and mesosphere is photodissociation of molecular oxygen. Chemical losses occur either through the Chapman (oxygen-only) reactions or through catalytic cycles involving $\mathrm{NO}_{\mathrm{x}}$ or $\mathrm{HO}_{\mathrm{x}}$ radicals. The major cycles relevant for odd oxygen are summarized in Tables 1-2. The most important reactions for a pure oxygen atmosphere are Reactions (R1-R8) (Table 1). Reactions (R1-R5) constitute net production and losses for odd oxygen. Reactions (R6R8) regulate partitioning between atomic oxygen and ozone within the odd oxygen family. Because of very rapid photolysis (Reaction R3 in Table 1) ozone concentration is low during the day but ozone reforms during both day and night by the 3-body Reaction (R4). 
Theoretical investigations have shown that, in addition to the photochemical schemes and reactions presented in Table 1 , catalytic reactions involving hydrogen species (Table 2) as well as turbulent mass transport are important.

At the altitudes where $\mathrm{O}$ and $\mathrm{H}$ have high abundances, catalytic cycles lead to more rapid odd oxygen loss than through the Chapman reactions only. For example, in the lower mesosphere odd oxygen is lost in catalytic reaction cycles (R4) and (R9) (Table 2):

Net: $\mathrm{O}_{3}+\mathrm{O} \rightarrow 2 \mathrm{O}_{2}$

The cycle (R6) and (R8) (Table 2):

Net: $\mathrm{O}_{3}+\mathrm{O} \rightarrow 2 \mathrm{O}_{2}$

becomes important in the middle and upper mesosphere.

Near $75-80 \mathrm{~km}$ odd hydrogen is produced primarily from photolysis of water vapor:

$\mathrm{H}_{2} \mathrm{O}+h v \rightarrow \mathrm{H}+\mathrm{OH}$

and therefore varies in proportion to $\mathrm{H}_{2} \mathrm{O}$. Below this region $\mathrm{OH}$ is produced by Reaction (R5) (Table 2) with $\mathrm{O}\left({ }^{1} \mathrm{D}\right)$ which itself is produced from $\mathrm{O}_{3}$ photolysis. Thus Reactions (R5) (Table 2), (R3) (Table 1) link OH production to the ozone amount: an increase in $\mathrm{OH}$ will decrease ozone and so decrease the amount of $\mathrm{OH}$ density. Since $\mathrm{OH}$ and $\mathrm{HO}_{2}$ are chemically active they are present in fairly low concentrations in quiet conditions.

During precipitation of solar protons (SPE), the concentration of the odd hydrogen constituents, $\mathrm{H}, \mathrm{OH}$ and $\mathrm{HO}_{2}$ increases. In particular, Solomon et al. (1981) pointed out that below $80 \mathrm{~km}$ nearly 2 odd hydrogen particles are formed per ionization and the subsequent reactions:

$\mathrm{H}+\mathrm{HO}_{2} \rightarrow \mathrm{OH}+\mathrm{OH}$

$\mathrm{H}+\mathrm{O}_{2}+\mathrm{M} \rightarrow \mathrm{HO}_{2}+\mathrm{M}$

produce $\mathrm{OH}$ and $\mathrm{HO}_{2}$. The transformation of precursor ions $\mathrm{O}_{2}^{+}$and $\mathrm{NO}^{+}$to intermediate hydrated clusters (Swider and Keneshea, 1973; Frederick, 1976; Solomon et al., 1981; Reid, 1977; Reid et al., 1991), with further clustering and dissociative recombination of water cluster ions, increases $\mathrm{OH}$ and $\mathrm{H}$ concentrations below the transition height in the mesosphere (the transition height being the height where the concentration of cluster ions equals the concentration of molecular ions). After the onset of a strong SPE these changes can become greater than 100\% (McPeters and Jackman, 1995; Jackman et al., 1995, 2005; Verronen et al., 2006).

During SPE the concentration of NO in the mesosphere is also increased strongly owing to dissociation and dissociative ionization of the nitrogen molecule $\mathrm{N}_{2}$ by relativistic protons and its dissociation by secondary electrons (Crutzen et al., 1975; Porter et al., 1976; Rusch et al., 1981; Jackman et al., 2005; Verronen et al., 2002; Lopez-Piertas et al., 2005). As a result of enhanced concentration of $\mathrm{NO}$ and hydrogen radicals, the catalytic cycles (Eqs. 1-2) become important in the mesosphere and lower thermosphere and as a consequence they lead to a change of the $\mathrm{O}_{3}$ and $\mathrm{O}$ densities. The character of the odd oxygen component variations under conditions of very strong solar proton precipitation depends on height, season, solar illumination and intensity of the corpuscular ionization source (Swider and Keneshea, 1973; Swider et al., 1978; Solomon et al., 1983; McPeters and Jackman, 1985; Smirnova et al., 1990; Seppälä et al., 2006, 2004; Jackman et al., 2005; Rohen et al., 2005; Verronen et al., 2005). Note that the last 4 of these studies include the same solar proton event as we study here.

Height profiles of ozone in the mesosphere deduced in different diffusive-photochemical models for daytime, quiet conditions are presented in Fig. 1 by curves 1-3 (Shimazaki and Laird, 1972; Rodrigo et al., 1986; Thomas and Bowman, 1985). Deviations in the concentration of ozone between $\mathrm{O}_{3}$ profiles 1-3 can be explained by differences in accounting for solar radiation intensity in different wavelength ranges, in absorption cross sections, in values of eddy diffusion coefficient, in concentration of atomic oxygen and other species, in rate constants of reactions and in other factors applied in the model studies. Nevertheless, at altitudes below $78-77 \mathrm{~km}$, the range of theoretical $\mathrm{O}_{3}$-profiles is close to the range of experimental values of the ozone concentration. In the upper mesosphere, above $80 \mathrm{~km}$, in several cases, the observed ozone abundance is larger than predicted by the photochemical models.

As has been mentioned above, even moderate SPE can cause ozone depletion of 30-70\%. According to Jackman et al. (2005), during the very strong SPE on 28-30 October 2003, changes in the concentration of NO and hydrogen radicals were significant and have also led to destruction of ozone. The hypothetical $\mathrm{O}_{3}$-profile 4 in Fig. 1 represents the height distribution of ozone decreased below $80 \mathrm{~km}$ altitude by a factor 2 compared with the minimum model $\mathrm{O}_{3}$ concentrations for quiet conditions (Swider and Keneshea, 1973; Rodrigo et al., 1986). The $\mathrm{O}_{3}$-profiles 5 and 6 represent $\mathrm{O}_{3}$ concentrations in the mesosphere obtained in a neutral chemistry model for the SPE-disturbed D-region (Swider and Keneshea, 1973; Swider et al., 1978) and measured by Weeks et al. (1972) during the SPE in November 1969.

\section{Influence of the ozone concentration on the ion com- position and electron density in the mesosphere}

To investigate the role of the ozone concentration in determining the ion composition and electron density profiles at mesospheric altitudes, we use a theoretical scheme describing the main ionic transformation processes and ionchemical reactions. This forms the basis of the theoretical chemical model applied in the present study and is described detail in Osepian et al. (2008). 
Table 1. Principal reactions for formation and destruction of odd oxygen.

\begin{tabular}{lll}
\hline No & Reactions & $\begin{array}{l}\text { Rate coefficient, } \mathrm{cm}^{3} \mathrm{~s}^{-1}, \mathrm{~cm}^{6} \mathrm{~s}^{-1} \\
\text { (DeMore, 1994; Sander et al., 2003) }\end{array}$ \\
\hline (R1) & $\mathrm{O}_{2}+h v(<1750 \AA) \rightarrow \mathrm{O}\left({ }^{3} \mathrm{P}\right)+\mathrm{O}\left({ }^{1} \mathrm{D}\right)$ & $4.10 \times 10^{-6}$ \\
$(\mathrm{R} 2)$ & $\mathrm{O}_{2}+h v(1750-2050 \AA) \rightarrow \mathrm{O}\left({ }^{3} \mathrm{P}\right)+\mathrm{O}\left({ }^{1} \mathrm{D}\right)$ & $1.87 \times 10^{-7}$ \\
$(\mathrm{R} 3)$ & $\mathrm{O}_{3}+h v(<3100 \AA) \rightarrow \mathrm{O}_{2}\left({ }^{1} \Delta_{g}\right)+\mathrm{O}\left({ }^{1} \mathrm{D}\right)$ & $9.63 \times 10^{-3}$ \\
& $\mathrm{O}_{3}+h v(3100-3600 \AA) \rightarrow \mathrm{O}_{2}\left({ }^{1} \Delta_{g}\right)+\mathrm{O}\left({ }^{3} \mathrm{P}\right)$ & $1.25 \times 10^{-4}$ \\
$(\mathrm{R} 4)$ & $\mathrm{O}\left({ }^{3} \mathrm{P}\right)+\mathrm{O}_{2}+\mathrm{M} \rightarrow \mathrm{O}_{3}+\mathrm{M}$ & $6.6 \times 10^{-34} \times(300 / T)^{2.3}$ \\
$(\mathrm{R} 5)$ & $\mathrm{O}+\mathrm{O}+\mathrm{M} \rightarrow \mathrm{O}_{2}\left({ }^{1} \Delta_{g}\right)+\mathrm{M}$ & $4.7 \times 10^{-33} \times(300 / T)^{2.0}$ \\
& & $9.2 \times 10^{-34} \times(470 / T)$ \\
$(\mathrm{R} 6)$ & $\mathrm{O}\left({ }^{3} \mathrm{P}\right)+\mathrm{O}_{3} \rightarrow \mathrm{O}_{2}+\mathrm{O}_{2}$ & $1.9 \times 10^{-11} \times \exp (-2300 / T)$ \\
& & $8.0 \times 10^{-12} \times \exp (-2060 / T)$ \\
$(\mathrm{R} 7)$ & $\mathrm{O}\left({ }^{1} \mathrm{D}\right)+\mathrm{O}_{3} \rightarrow \mathrm{O}_{2}+\mathrm{O}_{2}$ & $2.65 \times 10^{-10}$ \\
$(\mathrm{R} 8)$ & $\mathrm{O}\left({ }^{1} \mathrm{D}\right)+\mathrm{O}_{3} \rightarrow \mathrm{O}_{2}+2 \mathrm{O}\left({ }^{3} \mathrm{P}\right)$ & $2.65 \times 10^{-10}$ \\
(R9) & $\mathrm{N}\left({ }^{4} \mathrm{~S}\right)+\mathrm{O}_{3} \rightarrow \mathrm{NO}^{\circ} \mathrm{O}_{2}$ & $5.7 \times 10^{-13}$ \\
$(\mathrm{R} 10)$ & $\mathrm{O}_{3}+\mathrm{NO}+\mathrm{M} \rightarrow \mathrm{NO}_{2}+\mathrm{O}_{2}$ & $2.0 \times 10^{-12} \times \exp (-1400 / T)$ \\
$(\mathrm{R} 11)$ & $\mathrm{O}_{3}+\mathrm{NO} \rightarrow \mathrm{NO}_{2}+\mathrm{O}_{2}$ & $9.0 \times 10^{-13} \times \exp (-1200 / T)$ \\
& & $2.0 \times 10^{-12} \times \exp (-1400 / T)$ \\
$(\mathrm{R} 12)$ & $\mathrm{O}_{3}+\mathrm{NO}_{2} \rightarrow \mathrm{NO}_{3}+\mathrm{O}_{2}$ & $1.2 \times 10^{-13} \times \exp (-2450 / T)$ \\
\hline
\end{tabular}

Table 2. Reactions of odd oxygen with hydrogen species in the mesosphere.

\begin{tabular}{cll}
\hline No. & Reactions & $\begin{array}{l}\text { Rate constants, } \mathrm{cm}^{3} \mathrm{~s}^{-1}, \mathrm{~cm}^{6} \mathrm{~s}^{-1} \\
\text { (DeMore, } 1994 ; \text { Sander et al., 2003) }\end{array}$ \\
\hline (R1) & $\mathrm{O}+\mathrm{H}_{2} \rightarrow \mathrm{OH}+\mathrm{H}$ & $8.5 \times 10^{-20} \times T^{0.7} \times \exp (-3160 / T)$ \\
(R2) & $\mathrm{O}\left({ }^{3} \mathrm{P}\right)+\mathrm{H}_{2} \rightarrow \mathrm{OH}+\mathrm{H}$ & $2.5 \times 10^{-17} \times T^{2} \times \exp (-3801 / T)$ \\
& & $3.0 \times 10^{-14} \times T \times \exp (-4480 / T)$ \\
(R3) & $\mathrm{O}_{\mathrm{H}} \mathrm{O}_{2} \rightarrow \mathrm{OH}+\mathrm{HO}_{2}$ & $1.4 \times 10^{-12} \times \exp (-2000 / T)$ \\
(R4) & $\mathrm{O}+\mathrm{HO}_{2} \rightarrow \mathrm{OH}+\mathrm{O}_{2}$ & $3.0 \times 10^{-11} \times \exp (-200 / T)$ \\
(R5) & $\mathrm{O}\left({ }^{1} \mathrm{D}\right)+\mathrm{H}_{2} \mathrm{O} \rightarrow \mathrm{OH}+\mathrm{OH}$ & $2.2 \times 10^{-10}$ \\
& $\mathrm{O}\left({ }^{3} \mathrm{P}\right)+\mathrm{H}+\mathrm{M} \rightarrow \mathrm{OH}+\mathrm{M}$ & $3.0 \times 10^{-32}$ \\
(R6) & $\mathrm{O}+\mathrm{OH} \rightarrow \mathrm{O}_{2}+\mathrm{H}$ & $2.2 \times 10^{-11} \times \exp (-120 / T)$ \\
(R7) & $\mathrm{O}+\mathrm{OH}+\mathrm{M} \rightarrow \mathrm{HO}_{2}+\mathrm{M}$ & $1.4 \times 10^{-31}$ \\
(R8) & $\mathrm{O}_{3}+\mathrm{H} \rightarrow \mathrm{OH}+\mathrm{O}_{2}$ & $1.4 \times 10^{-10} \times \exp (-470 / T)$ \\
R9) & $\mathrm{O}_{3}+\mathrm{OH} \rightarrow \mathrm{HO}_{2}+\mathrm{O}_{2}$ & $1.6 \times 10^{-12} \times \exp (-940 / T)$ \\
(R10) & $\mathrm{O}_{3}+\mathrm{HO}_{2} \rightarrow \mathrm{OH}+2 \mathrm{O}_{2}$ & $1.1 \times 10^{-14} \times \exp (-500 / T)$ \\
& & $1.1 \times 10^{-13} \times \exp (-1250 / T)$ \\
\hline
\end{tabular}

Computations of the ionospheric parameters have been made during the SPE on 29 and 30 October 2003 at about local noon (at $1000 \mathrm{UT}, \chi=82.8^{\circ}$ and $83^{\circ}$ ), for different values of $\mathrm{O}_{3}$ concentration (the $\mathrm{O}_{3}$-profiles 1-6 in Fig. 1). Input values for nitric oxide (curve 1) and atomic oxygen (curve 2) for the autumn season are presented in Fig. 2.

The NO-profile has been deduced for the SPE on October 1968 in the model by Verronen et al. (2002). The concentration of nitric oxide is substantially larger than $[\mathrm{NO}]$ in quiet conditions. The effect of solar proton precipitation on atomic oxygen consists in depletion of [O]. The O-profile (curve 2) is taken from results of a neutral chemistry model for the SPE on 2 November 1969, using the methods described by Swider and Keneshea,(1973) and Swider et al. (1978).

For comparison we present the O-profile (curve 3) obtained for winter daytime mesosphere during the SPE on 17 January 2005 (Osepian et al., 2008). In both cases [O] is less than $[\mathrm{O}]$ in quiet conditions.

In our model we have incorporated changes of the odd oxygen concentration with zenith angle during twilight as in the simulation results by Turco and Sechrist (1972). We have further assumed a diurnal variation of the $\mathrm{NO}$ and $\mathrm{NO}_{2}$ 


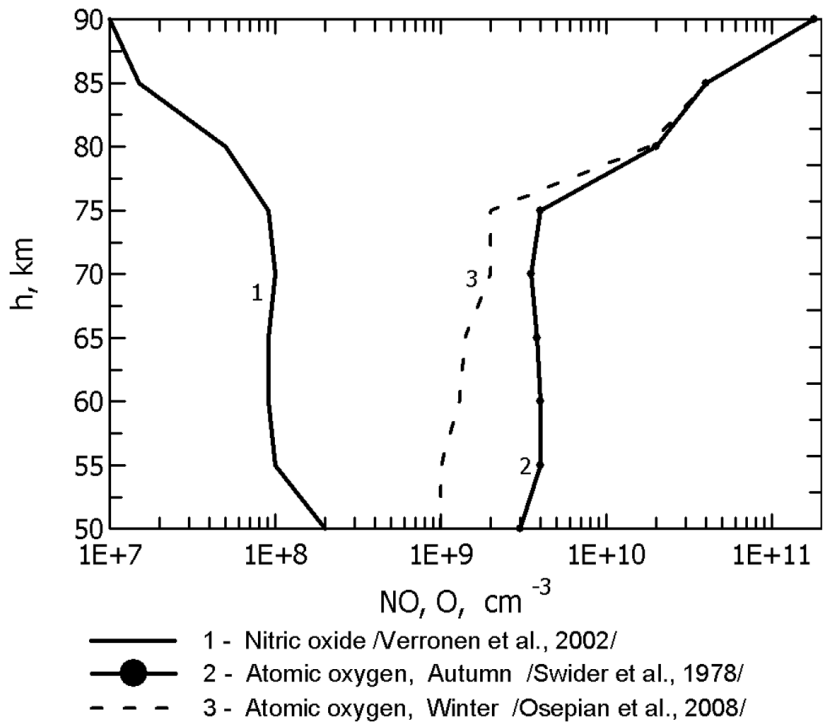

Fig. 2. Input values for nitric oxide (curve 1, Verronen et al., 2002) and atomic oxygen: curve 2 is for the autumn season (Swider et al., 1978) and curve 3 is for winter daytime (Osepian et al., 2008).

concentrations at altitudes below $70 \mathrm{~km}$ accordingly to the investigation results by Ogawa and Shimazaki (1975).

\subsection{Efficiencies of ion-molecular reactions forming complex negative ions in the lower ionosphere}

Variations of the $\mathrm{O}_{3}$ concentration are especially important for the negative ion chemistry. The primary negative $\mathrm{O}_{2}^{-}$ and $\mathrm{O}^{-}$ions participate in a complicated series of fast ionmolecular reactions with neutral constituents which produce different negative ions in the lower ionosphere, in particular, intermediate complex $\mathrm{O}_{3}^{-}, \mathrm{O}_{4}^{-}, \mathrm{NO}_{4}^{-}$ions (Table 3).

The intermediate ions $\mathrm{O}_{3}^{-}, \mathrm{O}_{4}^{-}, \mathrm{NO}_{4}^{-}$rapidly appear and disappear but they play a key role in formation of $\mathrm{NO}_{3}^{-}$and $\mathrm{NO}_{3}^{-}$ions. To understand the role of the ozone concentration in the ionisation balance at each altitude during SPE we have estimated the efficiencies of the ion-molecular reactions in the processes of transformation of primary negative $\mathrm{O}_{2}^{-}$and $\mathrm{O}^{-}$ions into intermediate complex ions $\mathrm{O}_{3}^{-}, \mathrm{O}_{4}^{-}, \mathrm{NO}_{4}^{-}, \mathrm{NO}_{3}^{-}$ and $\mathrm{NO}_{3}^{-}$.

We use $V_{\text {eff }}$ to denote the efficiency of individual reactions, e.g. for the efficiency of reaction $\mathrm{NO}_{4}^{-}+\mathrm{O}_{3} \rightarrow \mathrm{O}_{3}^{-}+\mathrm{NO}_{2}+\mathrm{O}_{2}$, $V_{\text {eff }}=1.3 \times 10^{-10}\left[\mathrm{O}_{3}\right]$. The efficiency of this reaction is equal to the product of the rate constant $k, \mathrm{~cm}^{3} \mathrm{~s}^{-1}$, and ozone concentration $\left[\mathrm{O}_{3}\right], \mathrm{cm}^{-3}$, i.e. it is the frequency of the reaction, $V_{\text {eff }}, \mathrm{s}^{-1}$.

As an example, in Fig. 3 we show efficiencies of the reactions in which $\mathrm{O}_{3}^{-}$ions are produced and lost. The main reactions producing $\mathrm{O}_{3}^{-}$ions are reactions forming $\mathrm{O}_{3}^{-}$from $\mathrm{O}_{2}^{-}$and $\mathrm{O}^{-}$:

$\mathrm{O}_{2}^{-}+\mathrm{O}_{3} \rightarrow \mathrm{O}_{3}^{-}+\mathrm{O}_{2}$

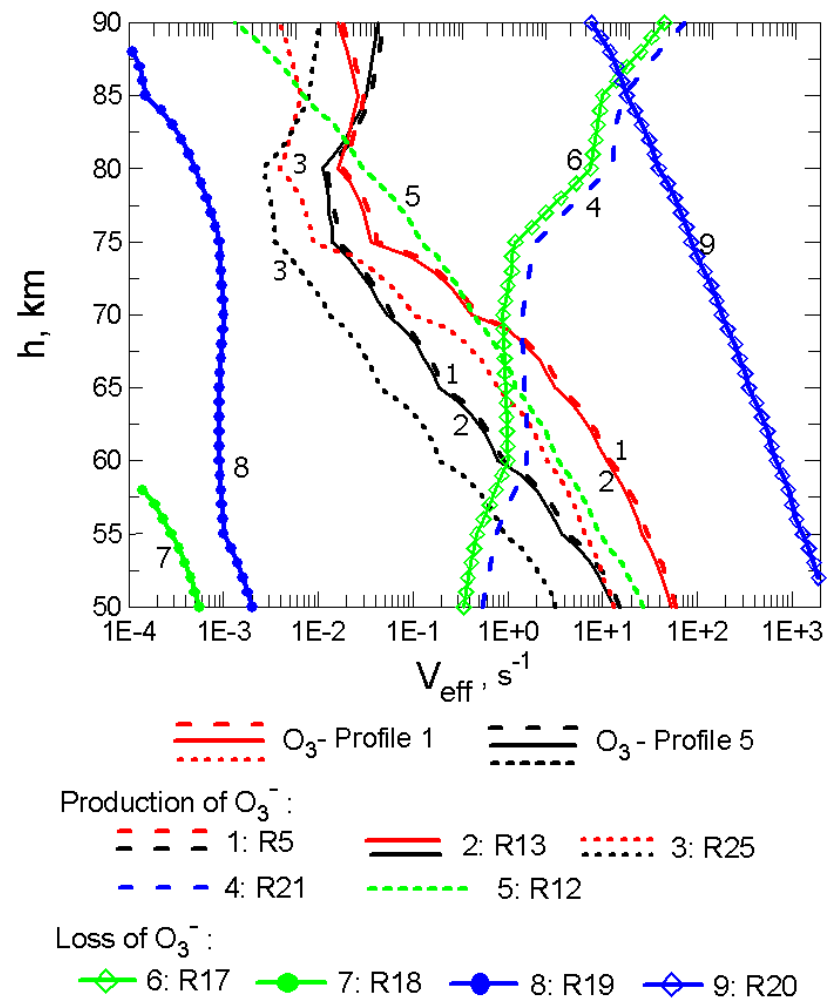

Fig. 3. Height profiles of the efficiencies of reactions for the $\mathrm{O}_{3}^{-}$ ion production and loss. Red and black lines correspond to ozone profiles 1 and 5, respectively, in Fig. 1. See text Sect. 3.1 for the various reaction paths $\mathrm{Rn}$.

$\mathrm{O}^{-}+\mathrm{O}_{3} \rightarrow \mathrm{O}_{3}^{-}+\mathrm{O}$

$\mathrm{O}^{-}+\mathrm{O}_{2}+\mathrm{O}_{2} \rightarrow \mathrm{O}_{3}^{-}+\mathrm{O}_{2}$

The efficiencies of these 3 reactions, calculated for $\mathrm{O}_{3}$ profiles 1 and 5, are given by curves 1,2 and 5 . The efficiencies of the reaction forming $\mathrm{O}_{3}^{-}$from $\mathrm{NO}_{4}^{-}$

$\mathrm{NO}_{4}^{-}+\mathrm{O}_{3} \rightarrow \mathrm{O}_{3}^{-}+\mathrm{NO}_{2}+\mathrm{O}_{2}$

are shown by curves 3. Efficiency of the reaction forming $\mathrm{O}_{3}^{-}$from $\mathrm{O}_{4}^{-}$

$\mathrm{O}_{4}^{-}+\mathrm{O} \rightarrow \mathrm{O}_{3}^{-}+\mathrm{O}_{2}$

is given by curve 4 .

Losses of the $\mathrm{O}_{3}^{-}$ions via reactions with participation of $\mathrm{NO}_{\mathrm{y}}$ are small:

$\mathrm{O}_{3}^{-}+\mathrm{NO}_{2} \rightarrow \mathrm{NO}_{3}^{-}+\mathrm{O}_{2}$

$\mathrm{O}_{3}^{-}+\mathrm{NO} \rightarrow \mathrm{NO}_{2}^{-}+\mathrm{O}_{2}$

At altitudes below $85 \mathrm{~km}$ the $\mathrm{O}_{3}^{-}$ions rapidly disappear in a reaction with $\mathrm{NO}_{2}$ :

$\mathrm{O}_{3}^{-}+\mathrm{NO}_{2} \rightarrow \mathrm{NO}_{3}^{-}+\mathrm{O}_{2}$ 
Table 3. Ion-molecular reactions forming complex negative ions from $\mathrm{O}_{2}^{-}$and $\mathrm{O}^{-}$.

\begin{tabular}{|c|c|}
\hline Reactions & Rate coefficient, $\mathrm{cm}^{3} \mathrm{~s}^{-1}, \mathrm{~cm}^{6} \mathrm{~s}^{-1}$ (Albritton, 1978) \\
\hline (R1) $\mathrm{O}_{2}^{-}+\mathrm{O}_{2} \rightarrow e+\mathrm{O}_{2}+\mathrm{O}_{2}$ & $3.0 \times 10^{-10}(300 / T)^{-0.5} \exp (-5590 / T)$ \\
\hline (R2) $\mathrm{O}_{2}^{-}+\mathrm{N}_{2} \rightarrow e+\mathrm{O}_{2}+\mathrm{N}_{2}$ & $1.9 \times 10^{-120}(300 / T)^{-1.5} \exp (-4990 / T)$ \\
\hline (R3) $\mathrm{O}_{2}^{-}+\mathrm{O} \rightarrow e+\mathrm{O}_{3}$ & $1.5 \times 10^{-10}$ \\
\hline (R4) $\mathrm{O}_{2}^{-}+\mathrm{O}_{2}\left({ }^{1} \Delta_{g}\right) \rightarrow e+\mathrm{O}_{2}+\mathrm{O}_{2}$ & $2.0 \times 10^{-10}$ \\
\hline (R5) $\mathrm{O}_{2}^{-}+\mathrm{O}_{3} \rightarrow \mathrm{O}_{3}^{-}+\mathrm{O}_{2}$ & $6.0 \times 10^{-10}$ \\
\hline (R6) $\mathrm{O}_{2}^{-}+\mathrm{CO}_{2}+\mathrm{O}_{2} \rightarrow \mathrm{CO}_{4}^{-}+\mathrm{O}_{2}$ & $2.0 \times 10^{-29}(300 / T)^{5.0}$ \\
\hline (R7) $\mathrm{O}_{2}^{-}+\mathrm{O}_{2}+\mathrm{O}_{2} \rightarrow \mathrm{O}_{4}^{-}+\mathrm{O}_{2}$ & $4.0 \times 10^{-31}(300 / T)^{5.0}$ \\
\hline (R8) $\mathrm{O}_{2}^{-}+\mathrm{H}_{2} \mathrm{O}+\mathrm{O}_{2} \rightarrow \mathrm{O}_{2}^{-} \mathrm{H}_{2} \mathrm{O}+\mathrm{O}_{2}$ & $1.6 \times 10^{-28}(300 / T)^{3.0}$ \\
\hline (R9) $\mathrm{O}_{2}^{-}+h v \rightarrow e+\mathrm{O}_{2}$ & $\rho_{1}=0.33 \mathrm{~s}^{-1}$ \\
\hline (R10) $\mathrm{O}^{-}+\mathrm{O}_{2}\left(1 \Delta_{g}\right) \rightarrow e+\mathrm{O}_{3}$ & $2.0 \times 10^{-10}$ \\
\hline (R11) $\mathrm{O}^{-}+\mathrm{CO}_{2}+\mathrm{O}_{2} \rightarrow \mathrm{CO}_{3}^{-}+\mathrm{O}_{2}$ & $3.1 \times 10^{-28}(300 / T)^{5.0}$ \\
\hline (R12) $\mathrm{O}^{-}+\mathrm{O}_{2}+\mathrm{O}_{2} \rightarrow \mathrm{O}_{3}^{-}+\mathrm{O}_{2}$ & $9.0 \times 10^{-31}(300 / T)^{5.0}$ \\
\hline (R13) $\mathrm{O}^{-}+\mathrm{O}_{3} \rightarrow \mathrm{O}_{3}^{-}+\mathrm{O}^{-}$ & $5.3 \times 10^{-10}$ \\
\hline (R14) $\mathrm{O}^{-}+\mathrm{O} \rightarrow e+\mathrm{O}_{2}$ & $1.9 \times 10^{-10}$ \\
\hline$(\mathrm{R} 15) \mathrm{O}^{-}+\mathrm{NO} \rightarrow e+\mathrm{NO}_{2}$ & $1.6 \times 10^{-10}$ \\
\hline (R16) $\mathrm{O}^{-}+\mathrm{H}_{2} \mathrm{O}^{\rightarrow} \mathrm{OH}^{-}+\mathrm{OH}$ & $1.4 \times 10^{-10}$ \\
\hline (R17) $\mathrm{O}_{3}^{-}+\mathrm{O} \rightarrow \mathrm{O}_{2}^{-}+\mathrm{O}_{2}$ & $2.5 \times 10^{-10}$ \\
\hline (R18) $\mathrm{O}_{3}^{-}+\mathrm{NO}_{2} \rightarrow \mathrm{NO}_{3}^{-}+\mathrm{O}_{2}$ & $2.8 \times 10^{-10}$ \\
\hline$(\mathrm{R} 19) \mathrm{O}_{3}^{-}+\mathrm{NO} \rightarrow \mathrm{NO}_{2}^{-}+\mathrm{O}_{2}$ & $1.0 \times 10^{-11}$ \\
\hline (R20) $\mathrm{O}_{3}^{-}+\mathrm{NO}_{2} \rightarrow \mathrm{NO}_{3}^{-}+\mathrm{O}_{2}$ & $4.0 \times 10^{-10}$ \\
\hline (R21) $\mathrm{O}_{4}^{-}+\mathrm{O} \rightarrow \mathrm{O}_{3}^{-}+\mathrm{O}_{2}$ & $4.0 \times 10^{-10}$ \\
\hline (R22) $\mathrm{O}_{4}^{-}+\mathrm{CO}_{2} \rightarrow \mathrm{CO}_{4}^{-}+\mathrm{O}_{2}$ & $4.3 \times 10^{-10}$ \\
\hline$(\mathrm{R} 23) \mathrm{O}_{4}^{-}+\mathrm{NO} \rightarrow \mathrm{NO}_{3}^{-}+\mathrm{O}_{2}$ & $2.5 \times 10^{-10}$ \\
\hline (R24) $\mathrm{O}_{4}^{-}+\mathrm{H}_{2} \mathrm{O} \rightarrow \mathrm{O}_{2}^{-} \cdot \mathrm{H}_{2} \mathrm{O}+\mathrm{O}_{2}$ & $1.5 \times 10^{-9}$ \\
\hline (R25) $\mathrm{NO}_{4}^{-}+\mathrm{O}_{3} \rightarrow \mathrm{O}_{3}^{-}+\mathrm{NO}_{2}+\mathrm{O}_{2}$ & $1.3 \times 10^{-10}$ \\
\hline (R26) $\mathrm{NO}_{4}^{-}+\mathrm{O} \rightarrow \mathrm{CO}_{3}^{-}+\mathrm{O}_{2}$ & $1.4 \times 10^{-10}$ \\
\hline$(\mathrm{R} 27) \mathrm{CO}_{3}^{-}+\mathrm{NO} \rightarrow \mathrm{NO}_{2}^{-}+\mathrm{CO}_{2}$ & $1.1 \times 10^{-10}$ \\
\hline (R28) $\mathrm{CO}_{3}^{-}+\mathrm{NO}_{2} \rightarrow \mathrm{NO}_{3}^{-}+\mathrm{CO}_{2}$ & $2.0 \times 10^{-10}$ \\
\hline (R29) $\mathrm{NO}_{3}^{-}+\mathrm{O}_{2} \rightarrow \mathrm{O}_{3}^{-}+\mathrm{CO}_{2}$ & $6.0 \times 10^{-15}$ \\
\hline$(\mathrm{R} 30) \mathrm{NO}_{3}^{-}+\mathrm{O} \rightarrow \mathrm{O}_{2}^{-}+\mathrm{CO}_{2}$ & $1.1 \times 10^{-10}$ \\
\hline
\end{tabular}

Above $85 \mathrm{~km}$ the $\mathrm{O}_{3}^{-}$ions again transform to $\mathrm{O}_{2}^{-}$ions through the reaction

$\mathrm{O}_{3}^{-}+\mathrm{O} \rightarrow \mathrm{O}_{2}^{-}+\mathrm{O}_{2}$

It is clear that variations of the ozone concentration affect the composition of negative ions mainly at altitudes below $70 \mathrm{~km}$.

In our theoretical model the efficiencies of reactions included in the paths (Eq. $4 \mathrm{a}, \mathrm{b})$ forming intermediate negative ions $\mathrm{O}_{3}^{-}, \mathrm{O}_{4}^{-}, \mathrm{NO}_{4}^{-}$from the primary ions $\mathrm{O}_{2}^{-}$and $\mathrm{O}^{-}$and their transformations into $\mathrm{NO}_{3}^{-}$ions:

$\mathrm{O}_{2}^{-} \rightarrow \mathrm{O}_{3}^{-}$and $\mathrm{O}_{4}^{-} \rightarrow \mathrm{CO}_{4}^{-} \rightarrow \mathrm{CO}_{3}^{-}$

$\mathrm{O}^{-} \rightarrow \mathrm{O}_{3}^{-} \rightarrow \mathrm{CO}_{3}^{-}$

are substituted by effective parameters $\mathrm{B}\left(\mathrm{O}_{2}^{-}\right), \mathrm{B}\left(\mathrm{O}^{-}\right)$. They are described by the expressions (A4) and (A5) in the Appendix of Osepian et al. (2008). The efficiencies of both channels calculated for $\mathrm{O}_{3}$-profiles 1 and 5 are shown by curves 1 and 2 in Fig. 4. First of all, note that the efficiency of reactions in the chain (Eq. $4 \mathrm{~b}), \mathrm{B}\left(\mathrm{O}^{-}\right)$, is greater than the efficiency of the path (Eq. 4a), $\mathrm{B}\left(\mathrm{O}_{2}^{-}\right)$, especially in the model with low $\left[\mathrm{O}_{3}\right]$. The influence of the ozone concentration on the efficiency of both paths becomes significant below $75 \mathrm{~km}$. The efficiency of the path (4a), $\mathrm{B}\left(\mathrm{O}_{2}^{-}\right)$, depends on the ozone concentration to a larger extent than $\mathrm{B}\left(\mathrm{O}^{-}\right)$.

The efficiencies of the main reactions which lead to losses of the $\mathrm{O}_{2}^{-}$and $\mathrm{O}^{-}$ions through channels (4a), (4b) (curves $\mathrm{B}\left(\mathrm{O}_{2}^{-}\right)$and $\left.\mathrm{B}\left(\mathrm{O}^{-}\right)\right)$and through reactions which do not produce negative ions (curves 2, 3):

$\mathrm{O}_{2}^{-}+\mathrm{O} \rightarrow e+\mathrm{O}_{3}$

$\mathrm{O}_{2}^{-}+\mathrm{O}_{2}\left({ }^{1} \Delta_{g}\right) \rightarrow e+\mathrm{O}_{2}+\mathrm{O}_{2}$ 


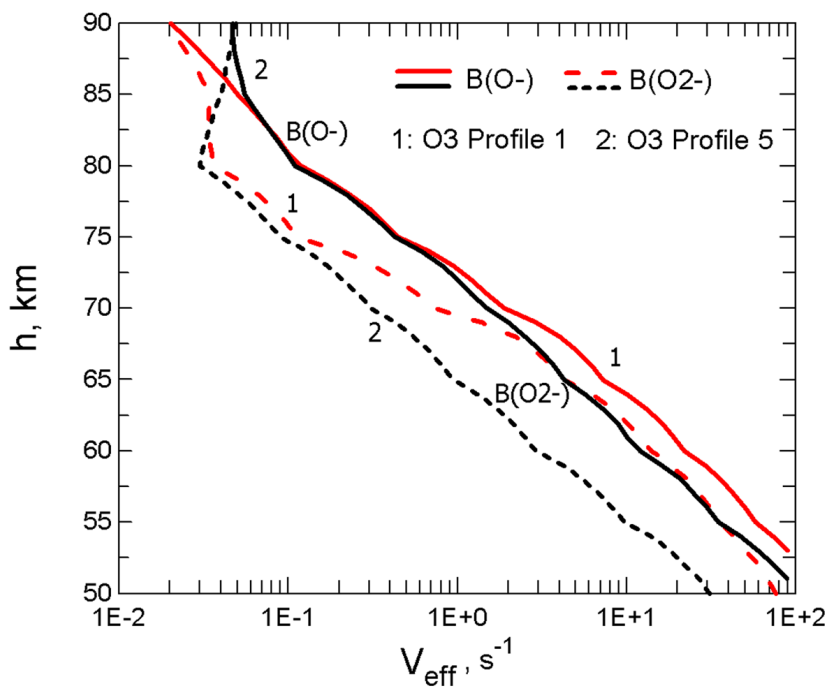

Fig. 4. Height profiles of the sum of the efficiencies, $\mathrm{B}\left(\mathrm{O}_{2}^{-}\right)$, and $\mathrm{B}\left(\mathrm{O}^{-}\right)$, of the reaction chains described by Eqs. (4a) and (4b). Red and black lines correspond to ozone profiles 1 and 5, respectively, in Fig. 1.

and

$\mathrm{O}^{-}+\mathrm{O} \rightarrow e+\mathrm{O}_{2}$

$\mathrm{O}^{-}+\mathrm{O}_{2}\left({ }^{1} \Delta_{g}\right) \rightarrow e+\mathrm{O}_{3}$

are compared in Fig. 5. The results of computations show that, in the model with low $\left[\mathrm{O}_{3}\right]$ concentration $\left(\mathrm{O}_{3}\right.$-profile 5), negative ions are mainly formed from the $\mathrm{O}^{-}$ion since the efficiency of the path $(4 \mathrm{~b}), \mathrm{B}\left(\mathrm{O}^{-}\right)$, is greater than $\mathrm{B}\left(\mathrm{O}_{2}^{-}\right)$and the efficiency of reactions $(6 \mathrm{a}, \mathrm{b})$. This process dominates at altitudes up to $73 \mathrm{~km}$. Production of complex negative ions from $\mathrm{O}_{2}^{-}$takes place only at altitudes below $\sim 58 \mathrm{~km}$ owing to the high efficiency of Reaction (5b). In the model with high $\left[\mathrm{O}_{3}\right]\left(\mathrm{O}_{3}\right.$-profile 1$)$ the path $(4 \mathrm{a})$ becomes effective at altitudes up to $\sim 70 \mathrm{~km}$. In both cases, at altitudes above $73 \mathrm{~km}$, formation of complex negative ions is broken, mainly due to processes of associative detachment (Eqs. 5a, 6a).

\subsection{Ion composition and electron density for different concentrations of ozone}

It is clear that the height distribution in the mesosphere of negative ions depends mainly on the $\mathrm{O}$ and $\mathrm{O}_{3}$ concentrations. Figure 6 (upper panel) demonstrates the influence of ozone concentration on the height distribution in the mesosphere of the main negative ions, $\mathrm{O}_{2}^{-}, \mathrm{O}^{-}, \mathrm{CO}_{3}^{-}$and $\mathrm{NO}_{3}^{-}$. It is seen that variations of ozone concentration lead to redistribution of the ion species abundances. A decrease of $\mathrm{O}_{3}$ concentration in the mesosphere strongly reduces the efficiency, $\mathrm{B}\left(\mathrm{O}_{2}^{-}\right)$, of Reaction (8a) forming $\mathrm{CO}_{3}^{-}$ions. In the model with low $\left[\mathrm{O}_{3}\right]\left(\mathrm{O}_{3}\right.$-profile 5$)$, the number density of $\mathrm{O}_{2}^{-}$ions

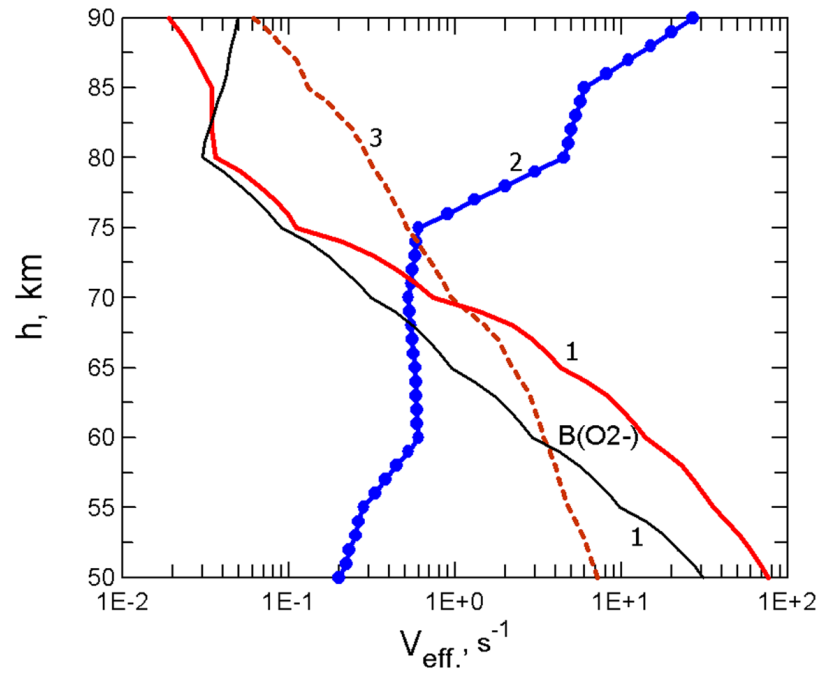

1: $\mathrm{B}(\mathrm{O} 2-), \mathrm{O} 3$ Profile $1-1: \mathrm{B}(\mathrm{O} 2-), \mathrm{O} 3$ Profile 5

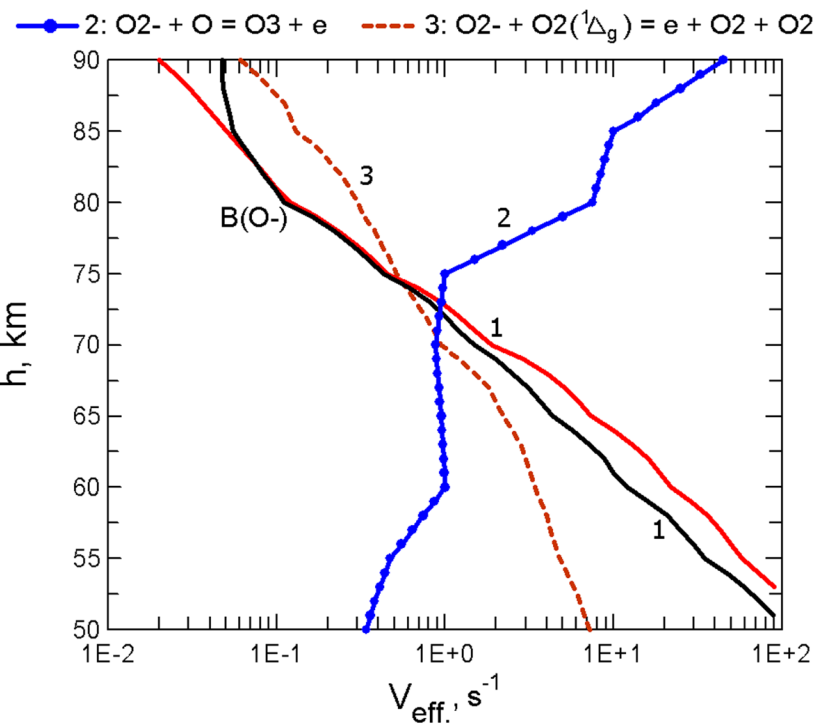

$\longrightarrow$ 1: B(O-), O3 Profile $1-1: B(O-), O 3$ Profile 5
$\longrightarrow 2: \mathrm{O}-\mathrm{O}=\mathrm{O} 2+\mathrm{e} \quad---3: \mathrm{O}-\mathrm{O} 2\left({ }^{1} \Delta_{\mathrm{g}}\right)=\mathrm{e}+\mathrm{O} 3$

Fig. 5. Upper panel: height profiles of the efficiencies of the reactions which lead to losses of the $\mathrm{O}_{2}^{-}$ion. Lower panel: height profiles of the efficiencies of the reactions which lead to losses of the $\mathrm{O}^{-}$ion. Curves 1 are efficiency of the channels $\mathrm{B}\left(\mathrm{O}_{2}^{-}\right)$and $\mathrm{B}\left(\mathrm{O}^{-}\right)$for the $\mathrm{O}_{3}$-profile 1 and 5. Curves 2 and 3 are efficiencies for reactions which do not produce negative ions.

at altitudes below $70 \mathrm{~km}$ is higher, but $\left[\mathrm{CO}_{3}^{-}\right]$and $\left[\mathrm{NO}_{3}^{-}\right]$are lower than in the model with high $\left[\mathrm{O}_{3}\right]\left(\mathrm{O}_{3}\right.$-profile 1$)$.

Figure 6 (lower panel) shows the height distribution in the mesosphere of the main positive molecular ions, $\mathrm{O}_{2}^{+}$, $\mathrm{NO}^{+}$, and clusters, $\mathrm{CL}^{+}{ }^{+}, \mathrm{CL}_{2}{ }^{+}$, computed for the $\mathrm{O}_{3}-$ profiles 1 and 5. Hydrated clusters in the form of $\mathrm{O}_{2}^{+} . \mathrm{X}$ and $\mathrm{NO}^{+}$.X, with recombination coefficient $\alpha \sim 2 \times 10^{-6} \mathrm{~cm}^{3} \mathrm{~s}^{-1}$, are combined into a Cluster ${ }_{1}^{+}$family $\left(\mathrm{CL}^{+}\right)$. The proton 

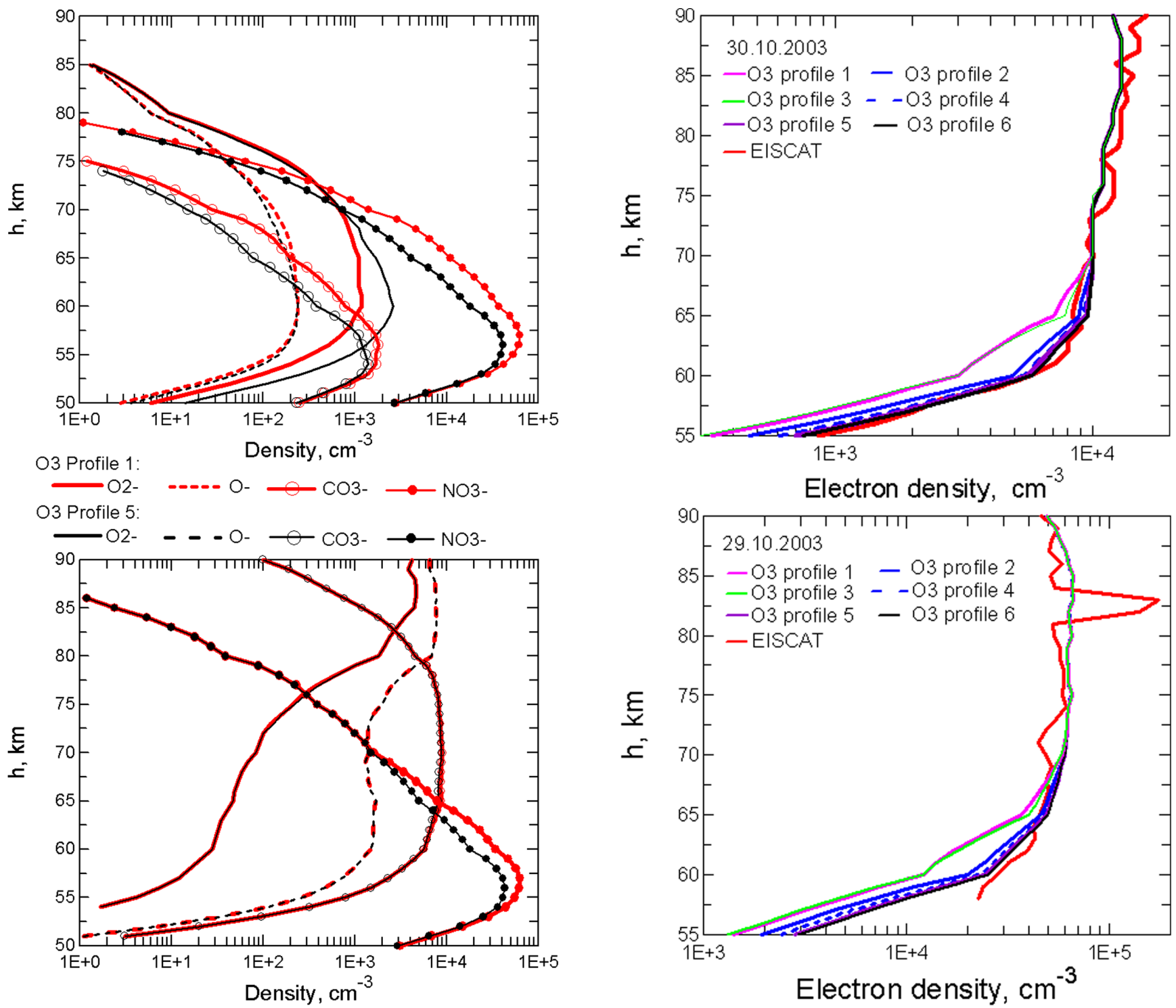

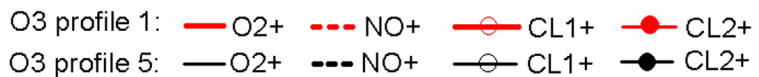

Fig. 6. Upper panel: height distribution of the main negative ions $\mathrm{O}_{2}^{-}, \mathrm{O}^{-}, \mathrm{CO}_{3}^{-}$and $\mathrm{NO}_{3}^{-}$for different profiles of ozone concentration $\mathrm{O}_{3}$-profile 1 (red) and $\mathrm{O}_{3}$-profile 5 (black). Lower panel: height distribution of the main positive molecular ions $\mathrm{O}_{2}^{+}, \mathrm{NO}^{+}$, and clusters $\mathrm{CL}_{1}{ }^{+}, \mathrm{CL}_{2}{ }^{+}$, computed for the $\mathrm{O}_{3}$-profiles 1 (red) and $\mathrm{O}_{3}$-profile 5 (black).

hydrates, which are created from $\mathrm{CL1} 1^{+}$, are combined into a Cluster ${ }_{2}^{+}$family $\left(\mathrm{CL} 2^{+}\right.$) with $\alpha \sim 1 \times 10^{-5} \mathrm{~cm}^{3} \mathrm{~s}^{-1}$. It is seen that a decrease of $\left[\mathrm{O}_{3}\right]$ by an order magnitude does not affect the number density of ions $\mathrm{CL}^{+}, \mathrm{NO}^{+}$and $\mathrm{O}_{2}^{+}$and only very slightly influences $\left[\mathrm{CL}^{+}\right]$below $68 \mathrm{~km}$. Cluster ions dominate over the simple molecular ions $\mathrm{NO}^{+}$and $\mathrm{O}_{2}^{+}$up to $79 \mathrm{~km}$ altitude in all cases. The concentration of the cluster

Fig. 7. Upper panel: The effect of different ozone concentrations $\left(\mathrm{O}_{3}\right.$-profiles 1-6) on the theoretical value of electron density at different altitudes for the SPE on 30 October 2003 at solar zenith angle $83.2^{\circ}$. Lower panel: The effect of different ozone concentrations $\left(\mathrm{O}_{3}\right.$-profiles 1-6) on the value of theoretical electron density at different altitudes for the SPE on 29 October 2003 at solar zenith angle $82.8^{\circ}$. Red curves are experimental (EISCAT) electron density profiles.

ion family, $\mathrm{CL}^{+}{ }^{+}$, is almost constant inside the height interval $57-78 \mathrm{~km}$ and then, above $78 \mathrm{~km}$, it decreases rapidly as a result of the decrease in the water vapour concentration. Under SPE conditions (high [NO]), the major ion at altitudes above $79 \mathrm{~km}$ is $\mathrm{NO}^{+}$. The cluster ion family $\mathrm{CL}_{2}{ }^{+}$dominates at altitudes below $63-62 \mathrm{~km}$.

Figure 7 shows the influence of the ozone concentration on the value of electron density at the different altitudes in 
the mesosphere. The theoretical $N_{e}$-profiles have been calculated on the basis of the $\mathrm{O}_{3}$-profiles 1-6. Results of the calculations are presented for the SPE on 30 October 2003 at 10:00 UT, solar zenith angle $(\chi)=83.2^{\circ}$, (upper panel), and on 29 October 2003 at 10:00 UT, $\chi=82.8^{\circ}$, (lower panel). First of all note that differences in the $\mathrm{O}_{3}$ concentration observed at altitudes above $70 \mathrm{~km}$ are not reflected in the value of electron density in the upper mesosphere. Effects of $\left[\mathrm{O}_{3}\right]$ on the electron density occur only in the lower mesosphere where negative ions play the main role in the ionization balance. Maximum changes of $N_{e}$ take place in the height range $55-65 \mathrm{~km}$. Here a decrease of $\left[\mathrm{O}_{3}\right]$ by about an order of magnitude $\left(\mathrm{O}_{3}\right.$-profiles $\left.1-4\right)$ causes enhancement of the electron density by a factor $\sim 1.5-2$. The maximum deviations in $\left[\mathrm{O}_{3}\right]$, between our hypothetical $\mathrm{O}_{3}$-profile 4 and the $\mathrm{O}_{3}$ profile 5 taken from the neutral chemistry model by Swider and Keneshea (1973) and the $\mathrm{O}_{3}$-profile 6 from Weeks et al. (1972), are about a factor 2 and a factor $\sim 4.5$, respectively. It is seen that they do not lead to such large differences in the value of $N_{e}$. The maximum changes in $N_{e}$ are a factor 1.2 or less.

Over the SPE period 28-30 October 2003, the most intensive fluxes of solar protons were measured on 29 October between 05:00 UT-12:00 UT. It can be seen in Fig. 8 (black curves) that the measured values of cosmic noise absorption, $A_{M}$, differ very strongly between 29 and 30 October. $A_{M}$ is the absorption measured by the vertical beam of the $38 \mathrm{MHz}$ IRIS riometer at Kilpisjärvi, $\sim 100 \mathrm{~km} \mathrm{SW}$ of EISCAT, scaled to $30 \mathrm{MHz}$ by multiplying by the factor $38^{2} / 30^{2}$. Red curves show absorption at $30 \mathrm{MHz}$ calculated on the basis of experimental (EISCAT) $N_{e}$-profiles, $A_{E}$.

Absorption is calculated using the Appleton-Hartree formula deduced from classical magneto-ionic theory:

$A=0.46 \int \frac{N_{e}(h) v_{e f}(h)}{\left(\omega \pm \omega_{L}\right)^{2}+v_{e f}^{2}(h)} d h$

where $\omega$ is the angular frequency of the radiowaves, $\omega_{L}=\Omega_{e} \cos \vartheta$, where $\Omega_{e}$ is the electron gyro-frequency, $\vartheta$ is the angle between the wave vector and geomagnetic field line, $N_{e}$ is the electron density at the altitude $h, v_{e f}(h)$ is the effective collision frequency of electrons with neutral particles. We use a radiowave frequency of $30 \mathrm{MHz}$ since this is a common standard for riometers and allows easy comparison with other publications.

For $v_{e f}(h)$ we use the expressions deduced by Banks (1966) from the measurements results of electron cross sections for momentum transfer with the neutral particles of the atmosphere $\left(\mathrm{N}_{2}, \mathrm{O}_{2}, \mathrm{O}\right.$,):

$v_{e f}=v\left(N_{2}\right)+v\left(O_{2}\right)+v(O)$

$v\left(\mathrm{~N}_{2}\right)=2.33 \times 10^{-11} \cdot\left[\mathrm{N}_{2}\right] \cdot\left(1-1.21 \times 10^{-4} T_{e}\right) \cdot T_{e}$

$v\left(\mathrm{O}_{2}\right)=1.82 \times 10^{-10} \cdot\left[\mathrm{O}_{2}\right] \cdot\left(1+3.6 \times 10^{-2} \cdot T_{e}^{1 / 2}\right) \cdot T_{e}^{1 / 2}$

$v(\mathrm{O})=2.8 \times 10^{-10} \cdot[\mathrm{O}] \cdot T_{e}^{1 / 2}$

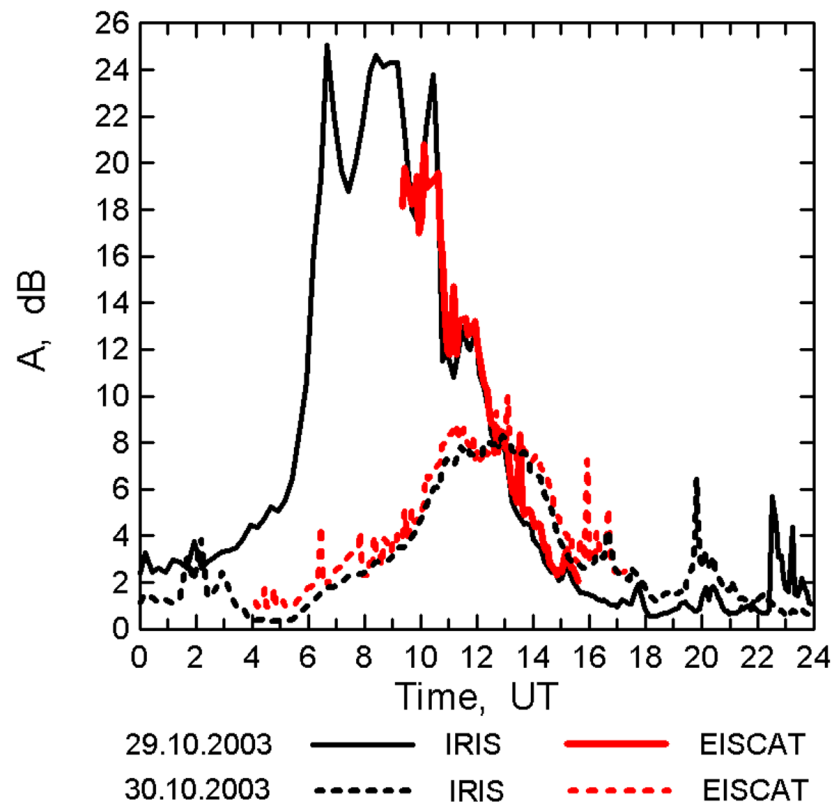

Fig. 8. Comparison of time series of the measured values of cosmic noise absorption from the IRIS riometer at Kilpisjärvi (black curves) with absorption calculated on the basis of experimental (EISCAT) $N_{e}$-profiles (red curves). The solid lines are on 29 October 2003, the dashed lines are on 30 October 2003. Absorption is given for a frequency of $30 \mathrm{MHz}$.

where $\left[\mathrm{N}_{2}\right],\left[\mathrm{O}_{2}\right],[\mathrm{O}]$ are concentrations of $\mathrm{N}_{2}, \mathrm{O}_{2}$ molecules (from the NRLMSISE-00 model of the neutral atmosphere, described by Picone et al., 2002) and of the atomic oxygen O (for SPE -from Osepian et al., 2008). Under condition of the thermal equilibrium $\left(T_{e}=T\right)$ the expressions (Eq. 8 gives values of $v_{e f}(h)$ very close to

$v_{e f}(h)=2.5 v_{m}(h)$

where $v_{m}(h)$ is expressed by Thrane and Piggott (1966) in terms of the atmospheric pressure $P$ :

$v_{m}(h)=6.38 \times 10^{5} \cdot P(h)$

Note also that for the cases which we consider, at 10:00 UT, the values of $A_{M}$ and $A_{E}$ almost coincide $\left(A_{M}=17.4 \mathrm{~dB}\right.$, $A_{E}=17.8 \mathrm{~dB}$ on 29 October $2003 ; A_{M}=4.5 \mathrm{~dB}, A_{E}=5.0 \mathrm{~dB}$ on 30 October 2003). Therefore in Fig. 7 we compare our theoretical $N_{e}$-profiles with $N_{e}$-profiles (red curves) measured by the incoherent scatter method to find which $\mathrm{O}_{3}$ profile best represents the SPE conditions. At 10:00 UT on 30 October, ionisation rates (Fig. 9) and electron densities were much smaller than at the same time on 29 October. In both cases model $N_{e}$-profiles based on the $\mathrm{O}_{3}$-profiles 4,5 and 6 match each other and are close to experimental values of electron density at all mesospheric altitudes.

In Fig. 10 we show $N_{e}$-profiles measured and calculated for other ionization rates and zenith angles (30 October 2003, 09:00 UT, $\chi=84.6$ upper panel; 12:30 UT, $\chi=85.8^{\circ}$ lower 

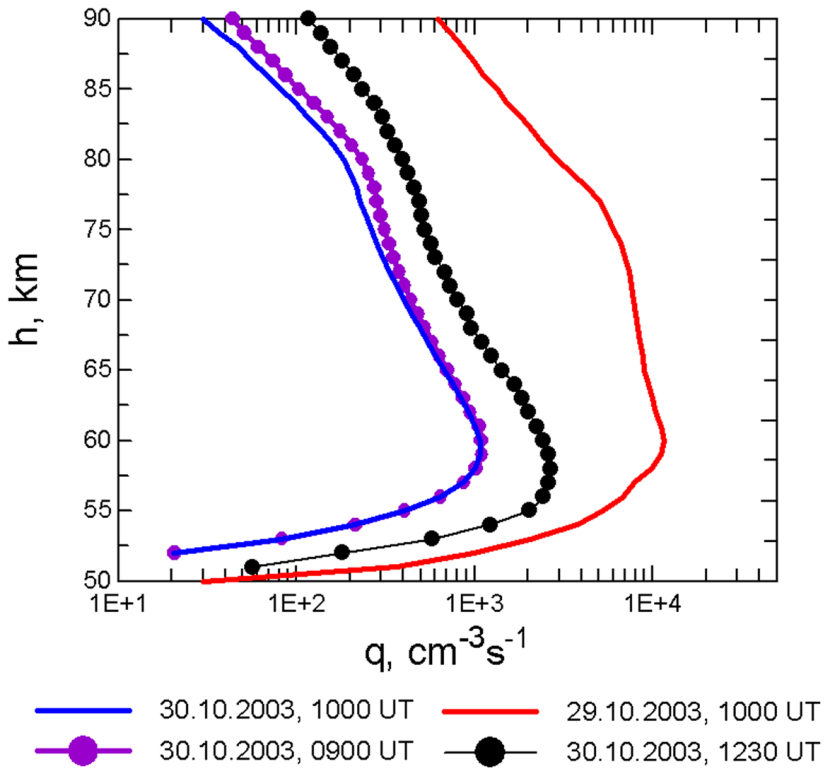

Fig. 9. Comparison of the ionisation rates on 29 October at 10:00 UT and on 30 October at 09:00, 10:00 and 12:30 UT.

panel) using $\mathrm{O}_{3}$-profiles $1,4,5$ and 6 . In these cases it is also seen that there is good agreement between experimental and model $N_{e}$-profiles for $\mathrm{O}_{3}$-profiles 4, 5 and 6 .

It is clear that very large ionization rates in the lower ionosphere caused strong ozone destruction. Concentrations of ozone consistent with the measured electron densities during the SPE on 29-30 October 2003 are low compared to available $\mathrm{O}_{3}$-profiles during quiet conditions, both those measured and those deduced in diffusion-photochemical models. The $\mathrm{O}_{3}$-profile 4 in Fig. 1 represents the maximum values of $\left[\mathrm{O}_{3}\right]$ in the autumn noon mesosphere needed for reproduction of experimental $N_{e}$-profiles in conditions of strong solar proton precipitation.

Figure 11 shows changes in the $\mathrm{O}_{3}$ concentration with changes in solar zenith angle, as used in our model calculations. The $\mathrm{O}_{3}$-profile 4 (local noon and $\chi<86^{\circ}$ ) is shown here by the red line. Our computations of electron density at other zenith angles $\left(87^{\circ}<\chi<95^{\circ}\right)$ have also shown good agreement between model and experimental values.

\section{Conclusion}

We have examined the influence of the ozone concentration on the height distribution of ion composition and electron density in the mesosphere during the SPE on 29 and 30 October 2003. Variations of $\left[\mathrm{O}_{3}\right]$ primarily affect the negative ion chemistry. The efficiencies, $\mathrm{B}\left(\mathrm{O}_{2}^{-}\right)$and $\mathrm{B}\left(\mathrm{O}^{-}\right)$, of the reactions forming intermediate negative ions, $\mathrm{O}_{3}^{-}, \mathrm{O}_{4}^{-}, \mathrm{CO}_{4}^{-}$, $\mathrm{CO}_{3}^{-}$, from primary negative ions $\mathrm{O}_{2}^{-}$and $\mathrm{O}^{-}$depend on $\mathrm{O}_{3}$ concentration at altitudes below $75 \mathrm{~km}$. This dependence is stronger for path (3.5a), i.e. $\mathrm{B}\left(\mathrm{O}_{2}^{-}\right)$.
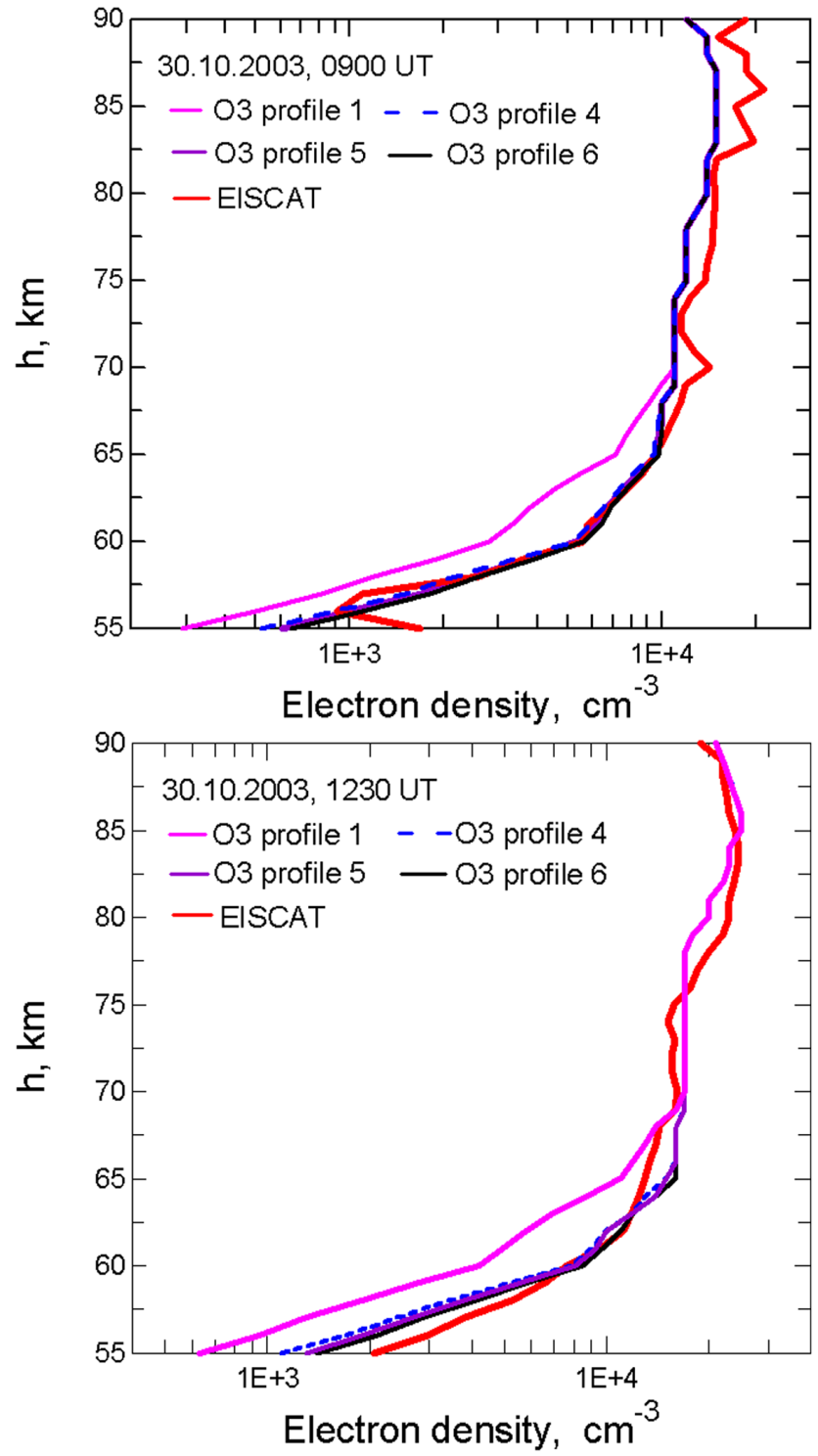

Fig. 10. Upper panel: electron density profiles measured and calculated on 30 October 2003 at 09:00 UT for zenith angle 84.6 $6^{\circ}$ Lower panel: electron density profiles measured and calculated on $30 \mathrm{Oc}$ tober 2003 at 12:30 UT for zenith angle $85.8^{\circ}$. The $\mathrm{O}_{3}$-profiles 1 , 4, 5 and 6 are used to obtain the modeled profiles.

In the model with low $\left[\mathrm{O}_{3}\right]$, the probability of production of intermediate ions from $\mathrm{O}_{2}^{-}$ions is much smaller than in the model with high $\left[\mathrm{O}_{3}\right]$. Moreover, the boundary, $h_{B}$, of the region where $\mathrm{O}_{2}^{-}$ions participate mainly in the production of complex negative ions, drops with decreasing $\left[\mathrm{O}_{3}\right]$ from $h_{B} \approx 68 \mathrm{~km}$ to $h_{B} \approx 58 \mathrm{~km}$ if $\left[\mathrm{O}_{3}\right]$ decreases by an order of magnitude. Above $h_{B}$ the losses of $\mathrm{O}_{2}^{-}$ions occur due to the high efficiencies for reactions of $\mathrm{O}_{2}^{-}$with excited oxygen $\mathrm{O}_{2}\left({ }^{1} \Delta_{g}\right)$ and atomic oxygen, which results in enhancement of the electron density. In our model computations, the path 


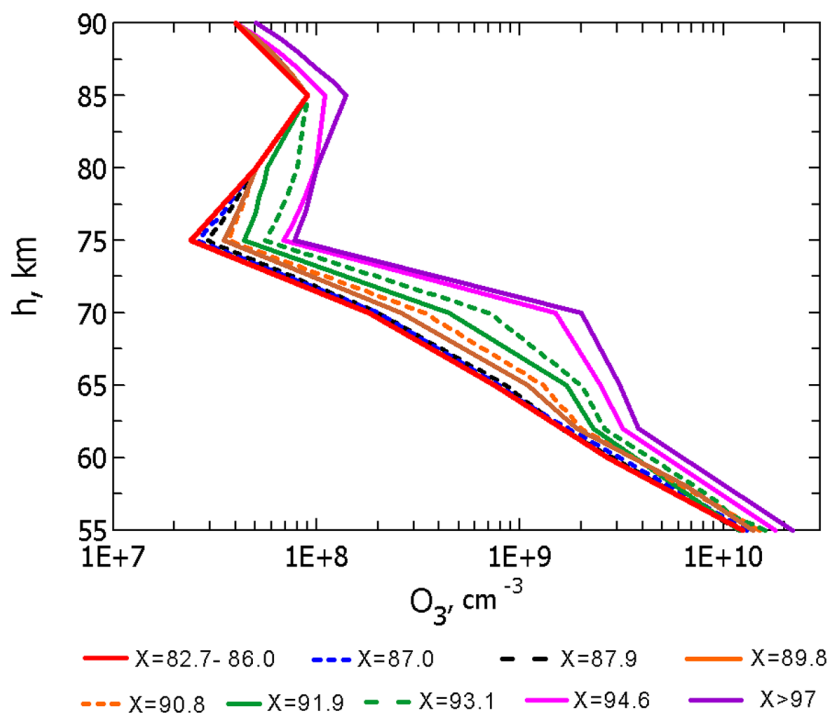

Fig. 11. Height profiles of the $\mathrm{O}_{3}$ concentration as a function of the solar zenith angle. The $\mathrm{O}_{3}$-profile 4 (local noon and $\chi<86^{\circ}$ ) is shown by the red line.

(4b), forming intermediate negative ions from $\mathrm{O}^{-}$ions, is more effective than the path from $\mathrm{O}_{2}^{-}$ions, $\mathrm{B}\left(\mathrm{O}^{-}\right)>\mathrm{B}\left(\mathrm{O}_{2}\right)$, and this path dominates up to $h_{B} \approx 73 \mathrm{~km}$, even in the model with low $\left[\mathrm{O}_{3}\right]$. At $h>73 \mathrm{~km}, \mathrm{O}^{-}$ions rapidly disappear through the reaction of associative detachment with atomic oxygen.

Thus variations of ozone concentration lead to redistribution of the negative ion species abundance. In the model with low $\left[\mathrm{O}_{3}\right]$, the number density of the $\mathrm{O}_{2}^{-}$ions is higher, but $\left[\mathrm{CO}_{3}^{-}\right]$and $\left[\mathrm{NO}_{3}^{-}\right]$are lower than in the model with high $\left[\mathrm{O}_{3}\right]$. As a result at heights below $70 \mathrm{~km}$, the total number density of negative ions decreases and electron density increases. The maximum changes of $N_{e}$ take place within the height range $55-65 \mathrm{~km}$.

Comparison of electron density profiles calculated by our numerical model, with the $N_{e}$-profiles measured by the EISCAT incoherent scatter radar during the strong SPE on 2930 October 2003, have given us the possibility to find which $\mathrm{O}_{3}$-profiles (at local noon and at zenith angles $87^{\circ}<\chi<95^{\circ}$ ) are consistent with experimental $N_{e}$ values. The result is presented in Fig. 11. It should be noted that the noon $\mathrm{O}_{3}$ profile 4, which we find is needed for an adequate fit to the experimental $N_{e}$ values during the very strong SPE on 29-30 October 2003, is close to the $\mathrm{O}_{3}$-profile deduced for full daytime in the neutral chemistry model by Swider and Keneshea (1973) and used by Swider et al. (1978) in the ion-chemistry model for the strong SPE during 2-5 November 1969. Deviations in $\left[\mathrm{O}_{3}\right]$ concentration between our study and Swider and Keneshea (1973), by about a factor 2, would result in changes of electron density less than 5-10\%. Further decrease of the $\mathrm{O}_{3}$ concentration would not lead to a noticeable effect on the ionization balance in the lower ionosphere.
Note also that the effects of the SPE-related $\mathrm{O}_{3}$ concentration depletion on the height distribution of ion and electron density occurs only in the lowermost part of the ionosphere, below $70 \mathrm{~km}$. This is different from the effect of atomic oxygen concentration which influences electron densities at all mesospheric altitudes (Osepian et al., 2008).

Summarizing, we have shown that reasonably accurate information on the height profile of the minor neutral constituent ozone is necessary for accurate modelling of the effective recombination coefficient, and hence the electron density profile, in the lower part of the D-region where negative ions dominate. We have shown that an ozone profile corresponding to strong depletion is needed to give model $N_{e^{-}}$ profiles consistent with observations during the strong SPE on 29-30 November 2003. Mesospheric ozone depletion was observed directly during this event (Rohen et al., 2005) and is likely a common feature of reasonably strong SPE. Simple incorporation of minor neutral constituent profiles (NO, O and $\mathrm{O}_{3}$ ), appropriate for SPE conditions, into ion-chemistry models will allow more accurate modeling of electron and ion densities during such events, without the need to apply a complete chemical model calculating all neutral species.

Acknowledgements. This research is partly supported by the RFFI grant No. 07-05-00012 and by the Swedish Academy of Sciences (KVA). EISCAT is an international association supported by China (CRIRP), Finland (SA), Germany (DFG), Japan (STEL and NIPR), Norway (NFR), Sweden (VR) and United Kingdom (STFC).

Topical Editor C. Jacobi thanks M. Friedrich and another anonymous referee for their help in evaluating this paper.

\section{References}

Albritton, D. L.: Ion-neutral reaction-rate constants measured in flow reactions through 1977, At. Data Nucl. Tables, 22, 1-101, 1978.

Crutzen, P. J., Isaksen, I. S. A., and Reid, G. C.: Solar proton events: stratospheric sources of nitric oxide, Science, 189, 457458, 1975.

DeMore, W. B., Sander, S. P., Golden, D. M, Molina, M. J., Hampson, R. F., Kurolo, M. J., Howard, C. J., and Ravishankara, A. R.: Chemical kinetics and Photochemical Data for Use in Stratospheric Modeling, JPL Publication 90-I, Jet Propulsion Laboratory, California Institute of Technology, Pasadena, USA, 1994.

Frederick, J. E.: Solar corpuscular emission and neutral chemistry in the earth's middle atmosphere, J. Geophys. Res., 81(19), 3179-3186, 1976.

Fussen, D., Vanhellemont, F., and Bingen, C.: Ozone profiles from 30 to $110 \mathrm{~km}$ measured by the Occultation Radiometer instrument during the period Aug. 1992-Apr. 1993, Geophys. Res. Lett., 27, 3449-3452, 2000.

Gumbel, J., Murtagh, D. P., Espy, P. J., Witt, G., and Schmidlin, F. J.: Odd oxygen measurements during the Noctilucent Cloud 93 rocket campaing, J. Geophys. Res. Space Phys., 103, 2339923414, 1998.

Jackman, C. H., Cerniglia, M. C., Nielsen, J. E., Allen, D. J., Zawodny, J. M., McPeter, R. D., Douglas, A. R., Rosenfield, J. E., 
and Hood, R. B.: Two-dimensional and three-dimensional model simulations, measurements and interpretation of the influence of the October 1989 solar proton events on the middle atmosphere, J. Geophys. Res., 100, 11641-11660, 1995.

Jackman, C. H., DeLand, M. T., Labow, G. J., Fleming, E. L., Weisenstein, D. K., Ko, M. K. W., Sinnhuber, M., Anderson, J., and Russell, J. M.: Neutral atmosphere influences of the solar proton events in October-November 2003, J. Geophys. Res., 110, A09S27, doi:10.1029/2004JA010888, 2005.

Kaufmann, M., Gusev, O. A., Grossmann, K. U., Martin-Torres, F. J., March, D. R., and Kutepov, A. A.: Satellite observations of daytime and nighttime ozone in the mesosphere and lower thermosphere, J. Geophys. Res., 108(D9), 4272, doi:10.1029/2002JD002800, 2003.

Keneshea, T. J., Zummermann, S. P., and Philbrick, C. R.: A dynamical model of the mesosphere and lower thermosphere, Planet. Space Sci., 27, 385-401, 1979.

Kirkwood, S. and Osepian, A.: Quantitative studies of energetic particle precipitation using incoherent scatter radar, J. Geomag. Geoelectr., 47, 783-799, 1995.

Kirkwood, S., Osepian, A., and Smirnova, N.: Quantitative description of electron precipitation during auroral absorption events in the morning/noon local time sector., J. Atmos. Sol. Terr. Phys., 63, 1907-1921, 2001.

Kyrölä, E., Tamminen, J., Leppelmeir, G. W., et al.: Nighttime ozone profiles in the stratosphere and mesosphere by the Global Ozone Monitoring by Occultation of Stars on Envisat, J. Geophys. Res., 111, D24306, doi:10.1029/2006JD007193, 2006.

Llewellyn, E. J. and Witt, G.: The measurement of ozone concentrations at high latitude during twilight, Planet. Space Sci., 25(2), $165-172,1977$.

López-Piertas, M., Funke, B., Gil-López, S., von Clarmann, T., Stiller, G. P., Hopfner, M., Kellmann, S., Fischer, H., and Jackman, C. H.: Observations of NO enhancement and ozone depletion in the Northern and Southern hemispheres after the OctoberNovember 2003 solar proton events, J. Geophys. Res., 110, A09S43, doi:10.1029/2005JA011050, 2005.

Marsh, D., Smith, A., and Noble, E.: Mesospheric ozone response to changes in water vapor, J. Geophys. Res., 108, D3 doi:10.1029/2002JD002705, 2003.

McPeters, R. D. and Jackman, C. H.: The response of ozone to solar proton events during solar cycle 21: The observations., J. Geophys. Res., 90, 7945-7954, 1985.

Ogawa, T. and Shimazaki, T.: Diurnal variations of odd nitrogen and ionic densities in the mesosphere and lower thermosphere: simultaneous solution of photochemical-diffusive equations, J. Geophys. Res., 80(28), 3945-3960, 1975.

Ondraskova, A., Krivolutsky, A. A., Kukoleva, A., Vyushkova, T., Kuminov, A., and Zakharov, G.: Response of the lower ionosphere to solar proton event on July 14, 2000. Model simulations over both poles, J. Atmos. Sol. Terr. Phys. 70, 539-545, 2008.

Osepian, A., Kirkwood S., and Smirnova, N.: Energetic electron precipitation during auroral events observed by incoherent scatter radar, Adv. Space Res., 17(11), (11)149-(11)155, 1996.

Osepian, A. and Smirnova, N.: Modelling of absorption layer during absorption events, J. Atmos. Sol. Terr. Phys., 59(8), 951-960, 1997.

Osepian, A., Tereschenko, V., Dalin, P., and Kirkwood, S.: The role of atomic oxygen concentration in the ionization balance of the lower ionosphere during solar proton events, Ann. Geophys., 26, 131-143, 2008,

http://www.ann-geophys.net/26/131/2008/.

Picone, J. M., Hedin, A. E., Drob, D. P., and Aikin, A. C.: NRLMSISE-00 empirical model of the atmosphere: Statistical comparisons and scientific issues, J. Geophys. Res., 107(A12), 1468, doi:10.1029/2002JA009430, 2002.

Polyakov, A. V., Timofeyev, Y. M., Ionov, D. V, Virolainen, Y. A., Steele, H. M., and Newchuch, M. J.: Retrieval of ozone and nitrogen dioxide concentrations from Stratospheric Aerosol and Gas Experiment III (SAGE III) measurements using a new algorithm, J. Geophys. Res., 110, D06303, doi:10.1029/2004JD005060, 2005.

Porter, H. S., Jackman, C. H., and Green, A. E. S.: Efficiencies for production of atomic nitrogen and oxygen by relativistic proton impact in air, J. Chem. Phys., 65, 154-165, 1976.

Reid, G. C.: The production of water cluster positive ions in the quiet daytime D-region, Planet. Space Sci., 25(3), 275-290, 1977.

Reid, G. C., Solomon, S., and Garcia, R. R.: Response of the middle atmosphere to the solar proton events of August-December, 1989, Geophys. Res. Lett., 18(6), 1019-1022, 1991.

Rohen, G., von Savigny, C., Sinnhuber, M., Llewellyn, E. J., Kaiser, J. W, Jackman, C. H., Kallenrode, M. B., Schroter, J., Eichmann, K. U., Bowensmann, H., and Burrows, J. P.: Ozone depletion during solar proton events of October/November 2003 as seen by SCIAMACHY, J. Geophys. Res., 110, A09S39, doi:10.1029/2004JA010984, 2005.

Rodrigo, R., López-Moreno, J. J., López-Puertas, M., Moreno, F., and Molina, A.: Neutral atmospheric composition between 60 and $220 \mathrm{~km}$ : A theoretical model for mid-latitudes, Planet. Space Sci., 34(8), 723-743, 1986.

Rusch, D. W., Gerard, J. C., Solomon, S., Crutzen, P. J., and Reid, G. C.: The effect of particle precipitation events on the neutral and ion chemistry of the middle atmosphere. I. Odd nitrogen, Planet. Space Sci., 29(7), 767-774, 1981.

Sandor, B. J., Clancy, R. T., Rusch, D. W., Randall, C. E., Eckman, R., Siskind, S., and Muchleman, D. O.: Microwave observations and modeling of $\mathrm{O}_{2}\left({ }^{1} \Delta_{2}\right)$ and $\mathrm{O}_{3}$ diurnal variation in the mesosphere, J. Geophys. Res., 102(D7), 9013-9028, 1997.

Sander, S. P., Friedl, R. R., Golden, D. M., et al.: Chemical kinetics and photochemical data for use in atmospheric studies: Evalution 14, JPL Publication 02-25, Jet Propulsion Laboratory, California Institute of Technology, Pasadena, USA, 2003.

Seppälä, A., Verronen, P. T., Kyrölä, E., Hassinen, S., Blackman, L., Houchecorne, A., Bertaux, J. L., and Fussen, D.: Solar proton events of October-November 2003: Ozone depletion in the northern hemisphere polar winter as seen by GOMOS/Envisat, Geophys. Res. Lett., 31, L19107, doi:10.1029/2004GL021042, 2004.

Seppälä, A., Verronen, P. T., Sofieva, V. F., Tamminen, J., Kyrölä, E., Rodger, C. J., and Clilverd, M. A.: Destruction of the tertiary ozone maximum during solar proton event, Geophys. Res. Lett., 33, L07804, doi:10.1029/2005GL025571, 2006.

Shimazaki, T. and Laird, A. R.: A model calculation of the diurnal variation in minor neutral constituents in the mesosphere and lower thermosphere including transport effects, J. Geophys. Res., 75, 3221-3235, 1970.

Shimazaki, T. and Laird, A. R.: Seasonal effect on distributions of 
minor constituents in the mesosphere and lower thermosphere, Radio Sci., 1, 23-43, 1972.

Smirnova, N. V., Ogloblina, O. F., and Vlaskov, V. A.: Modelling of the lower ionosphere Pageoph, 127, N.2/3, 353-379, 1988.

Smirnova, N. V., Vlaskov, V. A., and Kozlov, S. I.: Specialized aeronomic model for investigations of an artificial modification of the middle atmosphere and lower ionosphere. 2. Comparison of the model results with experimental data, Kosmicheskie Issledovania, 28, 1, 77-84, 1990 (in Russian).

Solomon, S., Rusch, D. W., Gerard, J. C., Reid, G. C., and Crutzen, P. J.: The effect of particle precipitation events on the neutral and ion chemistry of the middle atmosphere. II. Odd hydrogen, Planet. Space Science, 29(8), 885-892, 1981.

Solomon, S., Reid, G. C., Rusch, D. W., and Thomas, R. J.: Mesospheric ozone depletion during the solar proton event of July 1982. Part 2. Comparison between theory and measurements, Geophys. Res. Lett., 10(4), 257-260, 1983.

Swider, W. and Keneshea, T. J.: Decrease of ozone and atomic oxygen in the lower ionosphere during PCA event, Planet. Space Sci., 21(11), 1969-1973, 1973.

Swider, W., Keneshea, T. J., and Foley, C. I.: An SPE-disturbed D-region model, Planet. Space Sci., 26(9), 883-892, 1978.

Thomas, L. and Bowman, M. R.: Model studies of the D-region negative-ion composition during day-time and night-time, J. Atmos. Terr. Phys., 48(6), 547-556, 1985.

Thrane, E. W. and Pigott, W. R.: The collision frequency in the E- and D- regions of the ionosphere, J. Atmos. Terr. Phys., 28, 721-737, 1966.

Turco, R. P. and Sechrist, C. F.: An investigation of the ionospheric D-region at sunrise. 1. Time variations of ozone, metastable molecular oxygen and atomic oxygen, Radio Sci., 7(7), 703-716, 1972.

Ulwick, J. C., Baker, K. D., Baker, D. J., Steed, A. J., Pendleton Jr., W. R., Grossmann, K., and Bruckelmann, H. G.: Mesospheric minor species determinations from rocket and ground-based i.r. measurement, J. Atmos. Terr. Phys., 49(7/8), 855-862 1987.
Verronen, P. T., Turunen, E., Ulich, Th., and Kyrölä, E.: Modelling the effects of the October 1989 solar proton event on mesospheric odd nitrogen using a detailed ion and neutral chemistry model, Ann. Geophys., 20, 1967-1976, 2002, http://www.ann-geophys.net/20/1967/2002/.

Verronen, P. T., Seppälä, A., Cliverd, M. A., Rodger, C. J., Kyrölä, E., Enell, C. F., Ulich, T., and Turunen, E.: Diurnal variation of ozone depletion during the October-November 2003 solar proton event, J. Geophys. Res., 110, A09S32, doi:10.1029/2004JA010932, 2005.

Verronen, P. T., Seppälä, A., Kyrölä, E., Tamminen, J., Pickett, E., and Turunen, E.: Production of odd hydrogen in the mesosphere during January 2005 solar proton event, Geophys. Res. Lett., 33, L24811, doi:10.1029/2006GL028115, 2006.

Weeks, L. H., Cuikay, R. S., and Corbin, J. R.: Ozone measurements in the mesosphere during the solar proton event of November 2, 1969, J. Atmos. Sci., 29, 1138-1142, 1972.

Weeks, L. H., Good, R. E., Randhawa, J. S., and Trinks, H.: Ozone measurements in the stratosphere, mesosphere and lower thermosphere during Aladdin 74, J. Geophys. Res., 83, 978-982, 1978.

Wilson, W. J. and Schwart, P. R.: Diurnal variations of mesospheric ozone using millimeter - wave measurements, J. Geophys. Res., 86, 7385-7388, 1981.

Zhou, D. K., Mlynczak, M. G., Bingham, G. E., Wise, J. O., and Nadile, R. M.: CIRRIS-1A limb spectral measurements of mesospheric $9.6 \mu \mathrm{m}$ airglow and ozone, Geophys. Res. Lett., 25, 634646, 1998.

Zommerfields, W. C., Kinzi, K. F., Summers, M. E., Bevilacqua, R. M., Strobel, D. F., Allen, M., and Sawchuck, W. J.: Diurnal variations of mesospheric ozone obtained by groud-based microwave radiometry, J. Geophys. Res., 94, 12819-12832, 1989. 